UDC 678-19:539.3

\title{
REACTION EXTRUSION OF DYNAMIC ELASTOPLASTS ON THE BASIS OF POLYOLEFINES AND BUTADIEN-NITRIL RUBBER
}

\author{
${ }^{1}$ Z.N.Huseynova, ${ }^{1}$ N.T.Kakhramanov, ${ }^{2}$ V.S.Osipchik, ${ }^{1}$ R.V.Kurbanova, ${ }^{1}$ N.B.Arzumanova \\ ${ }^{1}$ Institute of Polymer Materials, NAS of Azerbaijan \\ ${ }^{2}$ D.Mendeleev University of Chemical Technology, Moscow \\ najaf1946@rambler.ru
}

Received 22.06.2018

\begin{abstract}
The influence of the concentration of butadiene-nitrile rubber and vulcanizing agents (dicumyl peroxide and sulphur) on the technological process of extrusion of elastoplasts on the basis of a mixture of lowdensity polyethylene and polypropylene is considered. It was found that with a minimum concentration of dicumyl peroxide ( 0.5 mass $\%$ ) or sulphur (1-5 mass $\%)$, it is possible to obtain dynamically vulcanized elastoplasts with a unique combination of structure and properties.
\end{abstract}

Keywords: ultimate tensile stress, modification, dynamic elastoplasts, elongation at break.

The improvement of various branches of industry have influence on conducting of researches aimed at developing new types of polymer materials, which sometimes possess unexpected and useful properties. Therefore, at the present time, crucial task is to conduct theoretical and experimental studies that open the possibility of obtaining materials with predetermined performance characteristics. One of the advanced polymer materials at present are thermoplastic elastomers (TEPs), obtained by the dynamic vulcanization method - dynamically vulcanized elastoplasts (DVEP). The latter circumstance became possible as a result of the mixing of various polymers, produced in the polymer industry [1-4]. In this case, it seemed possible to significantly influence the change in the micro- and macrostructure of the resulting composite materials and, accordingly, their properties. The most widespread were DVEP, prepared on the basis of a mixture of polyolefins with olefin or diene rubbers [5]. But their negative quality is low oil- and gasoline resistance, which significantly limits the area of their application. The oil-resistance of such DVEP can be substantially increased by replacing the nonpolar rubber with a polar one. The most common DVEP with increased oil resistance is made on the basis of a mixture of polyolefins with $\mathrm{SKN}$, which is due to the availability of components and their high resistance to hydrocarbons. However, low adhe- sion between these polymers causes not sufficient physical and mechanical properties of DVEP, even if dynamic vulcanization was conducted in the presence of such active crosslinking agents as organic peroxides. The most wellknown method for increasing the adhesion between phases in mixtures of dissimilar polymers is to introduce block or graft copolymers with blocks chemically identical to each polymer of the mixture. Such copolymers are called compatibilizers or additives promoting compatibility (APC). The assortment of such copolymers is extremely limited, and for a mixture of PP with SKN such copolymer is not produced. Accordingly, mixing polymers in an extruder or roller does not yet mean that in any combination could produce polymer compositions with improved properties. Numerous studies carried out by leading scientists in this direction have made it possible to arrive at an unambiguous conclusion about the need to take into account the compatibility and satisfactory miscibility of the selected research objects. In this case we are talking about the technological compatibility of polymer mixtures. Without taking into account these factors, it is hardly possible to achieve a real improvement in the properties of polymer compositions.

The most advanced direction is mechanochemical synthesis of DVEP based on multicomponent polymer mixtures, which are characterized by a unique combination of structure 
and operational properties. Possessing the properties of rubbers and the ability to process on standard equipment for processing thermoplastics, DVEP has become an indispensable material for the production on its basis of special construction products [5].

In this regard, the purpose of this paper is to study the influence of the technological aspects of reactive extrusion on the process of obtaining DVEP based on multi-polar polymer systems.

\section{Experimental part}

Low-density polyethylene (LDPE) with ultimate tensile stress of $13.3 \mathrm{MPa}$, elongation at break of $512 \%$, melting point of $102^{\circ} \mathrm{C}$ and MFR of $1.3 \mathrm{~g} / 10 \mathrm{~min}$ was used as the object of the study.

Polypropylene (PP) grade of PP 1500P, melting point $-160^{\circ} \mathrm{C}$, Vicat softening point $148^{\circ} \mathrm{C}$, flexural modulus $1400 \mathrm{MPa}$, ultimate tensile stress - $32.0 \mathrm{MPa}, 20 \%$ - elongation at break, melt flow rate (MFR) is $2.2 \mathrm{~g} / 10 \mathrm{~min}$ at $190^{\circ} \mathrm{C}$.

As an elastomer, butane-nitrile rubber grade of SKN-40 with molecular weight of 202200 , the Mooney viscosity at $100^{\circ} \mathrm{C}$ equal to 56 was used.

Dicumyl peroxide (DP) - a light yellow powder, with $T_{\mathrm{m}}=40^{\circ} \mathrm{C}$, is used as a crosslinking agent for polymers.

Graft copolymer - low density polyethylene with methacrylic acid (LDPE-MAA). The concentration of MAA in the graft copolymer composition is 32 mass $\%$.

The concentration of MAA in the grafts copolymer composition was determined in accordance with the previously developed IR spectral analysis [6].

The melt flow rate (MFR) was determined on the MELT FLOW TESTER rheometer, CEAST MF50 (INSTRON, Italy) at the temperature of $190^{\circ} \mathrm{C}$ and the load of $5 \mathrm{~kg}$.

The tensile stress at yield, ultimate tensile stress and elongation at break were determined in accordance with GOST 11262-80.

The melting point was determined on the derivatograph by Paulik-Paulik-Erdei.

Thermomechanical properties were deter- mined on the Kanavets plastometer. Deformation was measured at successively varying temperatures. Thermomechanical studies make it possible to obtain information on all possible physical, physico-chemical and chemical changes occurring in the samples during the process of changing the temperature of the experiment and, thereby, to obtain additional data on the temperature transitions that are significant for polymer processing.

Mechano-chemical synthesis of dynamically vulcanized elastoplasts was carried out during the process of reaction extrusion. Single screw extruder with the ratio $L / D=24$, consists of 4 zones: loading zone, compression zone, dosing zone, extruder head. The screw speed was adjusted with an asynchronous motor. The head is equipped with a slit attachment, which allows to obtain continuous sheets of thickness $2 \mathrm{~mm}$ and width of $100 \mathrm{~mm}$. From these sheets, blades were cut to determine the strength characteristics and elongation at break of polymer composite materials. After dry mixing of the components in a ball mill: $\mathrm{LDPE}+\mathrm{PP}+\mathrm{SKN}+\mathrm{DP}$ (or sulphur) was loaded into the extruder through the loading zone. The temperature of the material cylinder was selected depending on the type and ratio of the using components of the polymer mixture.

\section{Results and its discussion}

Before proceeding to study the technological aspects of extrusion of polymer mixtures, it seemed interesting to consider the effect of the ratio of the initial components of the LDPE+PP blend on the strength properties and elongation at break of composite materials. For this purpose, the curves for the dependence of the tensile stress at yield $\left(\sigma_{\mathrm{s}}\right)$, ultimate tensile stress $\left(\sigma_{d}\right)$ and elongation at break $(\varepsilon)$ on the ratio of components in the $\mathrm{PE}+\mathrm{PP}$ mixture are shown in Figure. Comparing the curves in this figure, we can establish that with an increase in the concentration of LDPE in the mixture, a regular decrease in $\sigma_{\mathrm{s}}$ and $\sigma_{\mathrm{d}}$ of the samples is observed. In this case, such a monotonous decrease in strength characteristics is due to their relatively low values for LDPE relative to PP. 


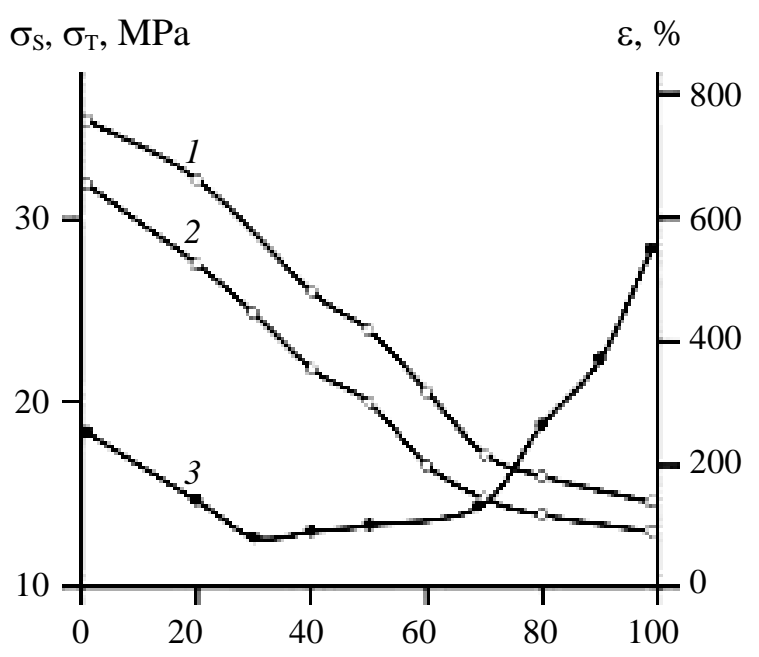

Influence of LDPE concentration on strength properties and elongation at break of polymer mixtures based on LDPE+PP: 1 - tensile stress at yield $\left(\sigma_{\mathrm{s}}\right), 2$ - ultimate tensile stress $\left(\sigma_{\mathrm{d}}\right), 3-$ elongation at break $(\varepsilon)$.

It is characteristic that for the initial PP the difference in the values of $\sigma_{\mathrm{s}}$ and $\sigma_{\mathrm{d}}$ is higher than in the case of LDPE. Along with this, with increasing LDPE concentration, a decrease in the elongation at break of the samples is observed at the initial moment (up to 30 mass \% of LDPE). In compositions containing more than 40 mass \% LDPE again there is an increase in the relative elongation of polymer mixtures. There is reason to believe that it is in compositions containing 40-50 mass \% LDPE phase reversal is observed, i.e. when the dispersed phase of LDPE becomes a dispersed medium. LDPE+PP blends are among the nonpolar hydrocarbon polymers of the polyolefin class and therefore we have the right to allow sufficient of their technological compatibility. However, they cannot be fully compatible because LDPE and PP differ not only in their molecular mass but also in their melting point, which are the fundamental factors that predetermine phase separation. If the melting point of the initial PP is $160^{\circ} \mathrm{C}$, and the LDPE is $102^{\circ} \mathrm{C}$, then this fact during cooling and crystallization becomes evident. Thus, for example, in the process of cooling the polymer mixture, the macrochains of the PP are crystallized at the initial time, and then LDPE. It is this difference in the crystalli- zation temperature of the components of the mixture that affects to a certain extent in their phase separation.

When choosing the optimum technological regime for extrusion of polymer compositions, studies aimed at investigating the influence of the temperature regime of the process and the speed of rotation of the screw on the productivity of the installation become the dominant role. One of the main factors affecting the performance of the extruder is the screw speed. However, an increase in the screw rotation speed is fraught with the production of a composite material with a non-uniform mutual dispersion of the components of the mixture. Therefore, during the extrusion process, it is necessary to select the screw rotation speed and the temperature regime in the material cylinder, in which the satisfactory quality of the obtained material would be well combined with a sufficiently high productivity of the extruder.

On the basis of the foregoing, Table 1 focuses on the study of the influence of the temperature regime on the zones of the material cylinder, the speed of rotation of the screw, and the extrusion pressure on such an important technological indicator of polymer materials, such as MFR. According to the data given in this table, it can be noted that as the concentrations of PP increases in the LDPE+PP mixture, an additive increase in the temperature regime of extrusion is observed. This is due primarily to the large difference in the melting temperatures of PP and LDPE. It is characteristics that along with this there is an increase in pressure in the extrusion apparatus. But this increase in pressure is associated not only with the introduction of PP, but also an increase in speed of the screw rotation from 13 to $16 \mathrm{rpm}$. The optimal condition for the extrusion processing of polymers is the maximum permissible capacity of the equipment. Therefore, in this paper, we tried to perform the extrusion process mainly under such conditions when the high productivity of the extruder would promote a uniform mutual dispersion of the polymer blends, without impairing the quality of the extruded product. 
Table 1. Optimum temperature regime of extrusion of the mixture of thermoplastic polyolefins LDPE+PP

\begin{tabular}{|c|c|c|c|c|}
\hline $\begin{array}{c}\text { Composition formulation, of the } \\
\text { mixture LDPE+PP, mass \% }\end{array}$ & $\begin{array}{c}\text { Extrusion temperature in } \\
\text { cylinder zones, } T, K\end{array}$ & $\begin{array}{c}\text { Extrusion pres- } \\
\text { sure, MPa }\end{array}$ & $\begin{array}{c}\text { Speed of rotation of } \\
\text { the screw, rpm }\end{array}$ & $\begin{array}{c}\text { MFR, } \\
\mathrm{g} / 10 \mathrm{~min}\end{array}$ \\
\hline LDPE & $100-120-140-150$ & 5.2 & 13 & 1.3 \\
LDPE+10PP & $110-140-165-180$ & 5.3 & 13 & 1.5 \\
LDPE+30PP & $120-150-170-180$ & 6.6 & 16 & 1.5 \\
LDPE+50PP & $120-150-180-190$ & 7.2 & 16 & 1.8 \\
LDPE+70PP & $130-150-180-200$ & 7.2 & 16 & 2.0 \\
PP & $\underbrace{140-160-1 \underbrace{8}_{3}-210}_{1}$ & 7.2 & 16 & 2.2 \\
\hline
\end{tabular}

*zones: 1 - loading, 2 - compression, 3 - dosing, 4 - extrude head.

From the presented Table 1 it follows that with an increase in the content of PP in the composition of the mixture, an increase in the temperature regime of processing, as well as the screw rotation speed and extrusion pressure is observed. At the same time, the MFR values of polymer mixtures occupy an intermediate position between the values of this index for LDPE and PP. The obtained data of the MFR allow us to assume that during the thermomechanical action on the melt of the polymer mixtures, there is no evidence of intense thermaloxidative degradation, which would otherwise lead to an increase in the MFR higher than that of the original components. When performing extrusion processing above or below the specified temperature optimum mode and pressure, it is usually accompanied by unjustified consumption of electricity or deterioration of the surface quality of the extruded product.

To obtain materials with elastoplastic properties, the SKN was introduced into the composition of the polymer mixture in question. Introduction SKN can help improve the properties of the compositions, provided that they are compatible with the polyolefin components of the mixture. With this end, we used the graft copolymer LDPE with methacrylic acid MAA as the compatibilizer PEMAA. It was necessary to reveal the role of PEMAA and SKN in changing the regime of extrusion of polymer mixtures. For carrying out the comparative analysis, we studied the regime of extrusion of polymer mixtures of $\mathrm{LDPE}+\mathrm{PP}+\mathrm{SKN}$ in the presence of the compatibilizer - PEMAA. At that, the ratio of LDPE:PP in all compositions was constant equal to 50:50.

The results of the investigation of the influence of SKN and PEMAA on the extrusion regime are presented in Table 2. Analysing the data presented in this table, it can be established that with an increase in the concentration of SKN in the polymer mixture, there is a certain tendency to reduce their optimum temperature range for their extrusion processing.

This is interpreted by the fact that as the concentration of the rubber component increases, the softening temperature of the polymer mixture decreases, which, correspondingly, affects a certain decrease in the temperature range of their extrusion processing. So, for example, thermomechanical studies carrying out on the Kanavets plastometer showed that the introduction of SKN in the amount of $-0,10,20,30$, 40, 50 mass \% in the composition of PP, which has the highest melting point $\left(160^{\circ} \mathrm{C}\right)$ in the polymer mixture, a decrease in the softening temperature is respectively corresponding to 151 , $145,140,106,101,93^{\circ} \mathrm{C}$.

Table 2. Influence of the concentration of SKN on the technological regime of extrusion of the polymer mixture of $\mathrm{LDPE}+\mathrm{PP}+\mathrm{SKN}+\mathrm{PEMAA}$ at the ratio of $\mathrm{LDPE} / \mathrm{PP}=50 / 50$.

\begin{tabular}{|c|c|c|c|c|}
\hline $\begin{array}{c}\text { Composition of the polymer mixture } \\
\text { with SKN and PEMAA, mass \% }\end{array}$ & $\begin{array}{c}\text { Extrusion temperature } \\
\text { in cylinder zones, } T, \mathrm{~K}\end{array}$ & $\begin{array}{c}\text { Extrusion } \\
\text { pressure, MPa }\end{array}$ & $\begin{array}{c}\text { Speed of rotation } \\
\text { of the screw, rpm }\end{array}$ & $\begin{array}{c}\text { MFR, } \\
\mathrm{g} / 10 \mathrm{~min}\end{array}$ \\
\hline 42.5LDPE+42.5PP+10SKN+5PEMAA & $130-160-190-210$ & 8.3 & 10 & 1.50 \\
37.5LDPE+37.5PP+20SKN+5PEMAA & $130-160-190-200$ & 8.4 & 10 & 1.23 \\
32.5LDPE+32.5PP+30SKN+5PEMAA & $130-160-180-200$ & 7.8 & 14 & 1.02 \\
27.5LDPE+27.5PP+40SKN+5PEMAA & $130-160-180-190$ & 7.4 & 14 & 0.85 \\
22.5LDPE+22.5PP+50SKN+5PEMAA & $\underbrace{130-160-180-190}_{1}$ & 7.5 & 14 & 0.33 \\
\hline
\end{tabular}

*zones: 1 - loading, 2 - compression, 3 - dosing, 4 - extrude head. 
At the same time, the process of transition from crystalline to highly elastic state for compositions with 30, 40 and 50 mas\% SKN-40, begins at a temperature equal to 141,143 and $135^{\circ} \mathrm{C}$, respectively. In this case, the decrease in MFR with increasing SKN concentration is associated with a high molecular weight of SKN (202200), while in LDPE it is equal to 105000 , and in PP, it is 125000 .

To obtain elastoplasts with clearly expressed rubber-like properties, it was interesting to establish the influence of the crosslinking agent on the processes taking place in the material cylinder of the extruder $[5,7,8]$. By selecting the ratio of the polymer components of the mixture and the cross-linking agent, it is possible to obtain DVEP with a unique combination of structure and properties in the process of reactive extrusion. Due to its structure, which is a dispersion of vulcanized rubber particles in a thermoplastic matrix, DVEP is characterized by a low swelling of the extrudates, which opens the possibility of obtaining molded products complicated in terms of profile in the process of extrusion molding. In short, extrusion processing of DVEP is a relatively easy and economical way of producing profiles for various applications (films, pipes, seals in the automotive industry and construction, etc.). The behaviour of the material in extrusion molding has much in common with injection molding, because the DVEP exhibits pronounced nonNewtonian properties during melt flow. According to these properties, the flow regime of the material is pseudo-plastic, varying depending on the applied shear stress. This indicates that the rheological features of the polymer melt are well regulated by the speed of rotation of the screw, the pressure created by the screw.

In this case, the process of reactive extrusion is based on the monotrem of technology, in which the mixing and vulcanization stages are combined. In this technological scheme provides for the application of the extrusion equipped with working zones such as the feed zone, plasticizing, mixing, compression, metering and granulation. At the same time, we allow the possibility of secondary processing of the material in the extruder, as a result of which it is possible to pro- duce DVEP with uniform dispersion of the mixture components, which provide them with stable physical and mechanical properties. Of course, in such cases it is necessary to pay special attention to the correct choice of the prescription and technological parameters of reactive extrusion. Thus, for example, DP with a concentration of no more than 0.5 mass. $\%$ was used as the crosslinking agent. The introduction of a relatively minimal number of DP is due to the need for crosslinking mainly over double SKN bonds, the number of which is many times higher than the concentration of different types of vinyl groups in LDPE and PP. The concentration of double bonds in SKN is on the average $4-5 \mathrm{~mol} \%$, whereas in LDPE and PP it is negligible, within $0.3-0.8 / 1000 \mathrm{C}$. At a concentration of DP above 0.5 mass \% peroxide radicals initiate crosslinking of macrochains not only in SKN, but also in thermoplastic polyolefins. Moreover, crosslinking can take place not only in double bonds, but also in tertiary carbon atoms, and also in methyl groups located at the $\alpha$-position to the terminal and transvinylenic double bonds. As a result of this cross-linking, a highly crosslinked spatial structure is formed in the polymer mixture, practically with a zero MFR value, which makes it impossible to process them by injection molding and extrusion methods. For example, when DP is introduced in the amount of $0.5,1.0,2.0$ mass $\%$, the content of the gel fraction, respectively, varies in the following sequence: 16,47 and 71 mass $\%$.

To obtain more complete information about the processes occurring in the melt under the conditions of reactive extrusion, let us turn to the results of the experimental studies given in Table 3. As can be seen from this table, with an increase in the concentration of the DP, there is a steady decrease in the MFR value of the DVEP samples, down to zero at 2 mass.\% containing crosslinking agent. This is especially problematic for compositions with initially low MFR. In this case, the possibility of their processing is completely prevented. An increase in the extrusion pressure at a constant screw speed indicates a sharp increase in the effective viscosity of the melt of DVEP, due to the formation of highly cross-linked spatial structure. 
Table 3. Influence of concentration of DP on the technological regime of extrusion of polymer mixtures (PM) and DVEP on their basis

\begin{tabular}{|c|c|c|c|c|}
\hline $\begin{array}{l}\text { Composition of the polymer mixture, } \\
\text { mass } \%\end{array}$ & $\begin{array}{c}\text { Extrusion tempera- } \\
\text { ture in cylinder } \\
\text { zones, } \\
T, \mathrm{~K}\end{array}$ & $\begin{array}{c}\text { Extrusion } \\
\text { pressure, } \\
\mathrm{MPa}\end{array}$ & $\begin{array}{l}\text { Speed of } \\
\text { rotation of } \\
\text { the screw, } \\
\text { rpm }\end{array}$ & $\begin{array}{l}\text { MFR, } \\
\text { g/10 min }\end{array}$ \\
\hline 27.5LDPE+27.5PP+40SKN+5PEMAA (PM) & $130-160-180-190$ & 7.4 & 14 & 0.85 \\
\hline $\mathrm{PM}+0.5 \mathrm{DP}$ & $130-160-180-190$ & 8.1 & 14 & 0.25 \\
\hline $\mathrm{PM}+1.0 \mathrm{DP}$ & $130-160-185-195$ & 10.9 & 14 & 0.09 \\
\hline $\mathrm{PM}+1.5 \mathrm{DP}$ & $130-170-190-200$ & 14.7 & 14 & 0.01 \\
\hline РМ+2.0 ПД & not recycled & - & - & 0 \\
\hline PM+1.0 sulphur & $130-160-180-190$ & 7.4 & 13 & 0.70 \\
\hline $\mathrm{PM}+2.0$ sulphur & $130-160-180-190$ & 7.4 & 13 & 0.64 \\
\hline PM+3.0 sulphur & $130-160-185-195$ & 7.9 & 13 & 0.59 \\
\hline $\mathrm{PM}+5.0$ sulphur & $130-160-185-195$ & 8.2 & 13 & 0.45 \\
\hline $\mathrm{PM}+10.0$ sulphur & $1 \underbrace{30}-1 \underbrace{70}-1 \underbrace{85}-1 \underbrace{95}$ & 8.6 & 13 & 0.31 \\
\hline & $\begin{array}{llll}1 & 2 & 3 & 4\end{array}$ & & & \\
\hline
\end{tabular}

*zones: 1 - loading, 2 - compression, 3 - dosing, 4 - extrude head.

In this connection, it seemed interesting to consider the possibility of using sulfur as the vulcanizing agent of polymer mixtures. Comparison of experimental data in Table 3 allows us to state that the use of sulfur as a vulcanizing agent facilitates the mechano-chemical synthesis under reactionary extrusion conditions in a relatively soft mode. Thus, for example, at the same screw speed, with an increase in sulfur concentration, the extrusion pressure changes to a comparatively lesser degree than in the case of using the DP as a cross-linking agent. A slight change in the extrusion pressure also indicates that there is no sharp increase in the viscosity of the melt, i.e. we can assume the formation of a rare-crosslinked structure, mainly due to vinyl groups of SKN. If allowed of occurring of the cross-linking possible mainly due to the vinyl groups of LDPE and PP, this, as in the case of the use of PD in the amount of more than 0.5 mass. $\%$, would lead to a substantial decrease in the MFR of the samples. The flowability of DVEP determines the thermoplastic components of the mixture. Therefore, any sharp fluctuations in the flowability of the melt of DVEP can be due to the passing interchain chemical processes. A slight decrease in the MFR of the samples is due to the influence of the crosslinked structures of the dispersed rubber phase on the rheology of the composition. The obtained data allow to consider that sulfur vulcanization and vulcanization of incompatible polymer mixtures with a minimum concentration of DP equal to 0.5 mass.\% is the most optimal variant of obtaining DVEP with improved technological characteristics.

Thus, based on the foregoing, it can be stated that the monotrem technology of simultaneous mixing and vulcanizing of polymer mixtures is the most accessible and effective method of obtaining DVEP with improved technological characteristics.

\section{References}

1. Nguen Min' Tuan, Chalaja N.M., Osipchik V.S. Struktura i fiziko-mehanicheskie svojstva smesej polipropilena i metallocenovogo jetilenpropilenovogo jelastomera // Plast. massy. 2017. № 9-10. S. $12-16$.

2. Simonov-Emel'janov I.D. Principy sozdanija i pererabotki kompozicionnyh materialov dispersnoj struktury // Plast. massy. 2005. № 1. S. 11-16.

3. Kravchenko T.P., Ermakov S.N., Kerber M.L. Nauchno-tehnicheskie problemy poluchenija kompozicionnyh materialov na osnove konstrukcionnyh termoplastov // Plast. massy. 2010. № 10. S. 32-37.

4. Kahramanly Ju.N. Nesovmestimye polimernye smesi i kompozicionnye materialy na ih osnove. Baku.: Elm, 2013. 152 s.

5. Volfson S.I. Dinamicheski vulkanizovannye termojelastoplasty. Poluchenie, pererabotka, svojstva. M.: Nauka, 2004. 173 s.

6. Kahramanov N.T., Kahramanova H.T. IKspektralnyj analiz struktury privityh sopolimerov PJe s akrilovymi monomerami // Azerb. him. zhurn. 2004. № 2. S. 156-158.

7. Kazakov Ju.M., Volkov A.M., Ryzhikova I.G., Bauman N.A., Volfson S.I. Binarnye smesi 
jetilen- $\alpha$-olefinovyh jelastomerov dlja uluchshenija balansa udaro- i deformacionno-prochnostnyh harakteristik kompozicij polipropilena, poluchaemyh $\mathrm{v}$ processe reakcionnoj jekstruzii // Plast. massy. 2016. № 9-10. S. 3-6.
8. Kazanchan A.Je., Osipchik V.S., Chalaja N.M., Kikel V.A. Modificirovanie svojstv himicheski sshitogo polijetilena termojelastoplastami // Plast. massy. 2012. № 1. S. 3-7.

\section{POLIOLLFINLəR Və BUTADIEN-NITRIL KAUÇUKU OSASINDA DINAMIK ELASTOPLASTLARIN REAKSIYYALI EKSTRUZIYASI}

\section{Z.N.Hüseynova, N.T.Qəhrəmanov, V.S.Osipçik, R.V.Qurbanova, N.B.Arzumanova}

Butadien-nitril kauçuku və vulkanlaşdırıcı agentlərin (dikumil peroksid və kükürd) aşağı sıxlıqlı polietilen və polipropilen qarışığı əsasında elastoplastların ekstruziya yolu ilə alınmasının texnoloji prosesinə təsiri nəzərdən keçirilmişdir. Müəyyən olunmuşdur ki, dikumil peroksidin (0.5 kütlə\%) və kükürdün (1-5 kütlə\%) minimal miqdarlarında quruluş və xassələrin unikal uyğunluğuna malik dinamiki vulkanlaşdırılmış elastoplastların alınması imkanı yaranır.

Açar sözlər: dartılmada möhkamlik haddi,modifikasiya, dinamik elastoplastlar, nisbi uzanma.

\section{РЕАКЦИОННАЯ ЭКСТРУЗИЯ ДИНАМИЧЕСКИХ ЭЛАСТОПЛАСТОВ НА ОСНОВЕ ПОЛИОЛЕФИНОВ И БУТАДИЕН-НИТРИЛЬНОГО КАУЧУКА}

\section{З.Н.Гусейнова, Н.Т.Кахраманов, В.С.Осипчик, Р.В.Курбанова, Н.Б.Арзуманова}

Рассмотрено влияние концентрации бутадиен-нитрильного каучука и вулканизующих агентов (пероксида дикумила и серы) на технологический процесс экструзии эластопластов на основе смеси полиэтилена низкой плотности и полипропилена. Установлено, что при минимальной концентрации пероксида дикумила (0.5 масс.\%) или серы (1-5 масс.\%) представляется возможным получение динамически вулканизованных эластопластов с уникальным сочетанием структуры и свойств.

Ключевые слова: разрушающее напряжение, модификация, динамические эластопласты, относительное удлинение. 